\title{
PENGUATAN KAPASITAS BUMG BERSAMA MINAPOLITAN MEURASA SABAN KABUPATEN ACEH TIMUR MELALUI EDUTEKNOPRENEURSHIP
}

\author{
Baihaqi $^{1)}$, Syardiansah ${ }^{2)}$, Zulkarnen Mora ${ }^{2)}$ \\ 1) Prodi Pendidikan Bahasa Inggris, Fakultas Keguruan dan Ilmu Pendidikan, Universitas Samudra, Jalan \\ Meurandeh, Meurandeh, Langsa Lama, Kota Langsa, Aceh 24354 \\ 2) Prodi Manajemen , Fakultas Ekonomi, Universitas Samudra, Jalan Meurandeh, Meurandeh, Langsa Lama, \\ Kota Langsa, Aceh 24354 \\ e-mail: ikmacehtamiang@gmail.com
}

\begin{abstract}
Gampong-Owned Enterprises (BUMG) Minapolitan Meurasa Saban is a business entity owned by five villages (bale buya, matang gleum, kuala leuge, seuneubok peusangan and seuneubok pidie). With one of their business is BUMDES Mart Minapolitan Meurasa Saban. The weakness of administrative and financial as well as manual product registration are problems encountered in marketing the products on display at BUMG. The purpose of this program is to improve administrative and financial management staffs based on edutechno preneurship. The activity was carried out for five months starting from May to September 2019. The activities involved 15 BUMG management and supervisors of Minapolitan Meurasa Saban. The method used is discussion and active participation of the target group by applying adult learning model. The activities were carried out in several stages which included coordination, socialisation, training and mentoring activities. The results of the evaluation of the implementation of the activity showed that there was an increase in the capacity of BUMG's Bersama Minapolitan Meurasa Saban supervisors and management staffs on improving BUMG's administrative and financial governance. The results of the questionnaire showed that ten administrators $(75 \%)$ understood all the training material well, while five administrators $(25 \%)$ understood all the training material. The level of satisfaction of the training participants showed 12 managers (85\%) were very satisfied, and three administrators (15\%) were satisfied with the implementation of the training. BUMG Bersama Minapolitan Meurasa Saban supervisors and administrators have understood AD / ART and TUPOKSI, whereas the treasurer and operator of BUMG Bersama Minapolitan Meurasa Saban are able to understand the edutechnopreneurship-based product registration, BUMG Bersama Minapolitan Meurasa Saban has a business development plan as stated in the annual work program
\end{abstract}

Keywords: BUMG Bersama Minapolitan Meurasa Saban, Aceh Timur District, Edutechnopreneurship

\begin{abstract}
Abstrak
Badan Usaha Milik Gampong (BUMG) Bersama Minapolitan Meurasa Saban merupakan badan usaha yang dimiliki oleh 5 gampong (bale buya, matang gleum, kuala leuge, seuneubok peusangan dan seuneubok pidie). Dengan salah satu usahanya adalah BUMDES Mart Bersama Minapolitan Meurasa Saban. Lemahnya penatausahaan administrasi dan keuangan serta pencatatan produk secara manual menjadi permasalahan yang dihadapi dalam memasarkan produk-produk yang dipajang pada BUMG tersebut. Tujuan dari kegiatan ini adalah perbaikan tatakelola administrasi dan keuangan berbasis eduteknopreneurship. Kegiatan dilakukan selama 5 bulan mulai Mei -September 2019. Kegiatan pengabdian kepada masyarakat melibatkan 15 pengurus dan pengawas BUMG Bersama Minapolitan Meurasa Saban. Metode yang digunakan berupa diskusi dan partisipasi aktif dari kelompok sasaran dengan menerapkan pola pembelajaran orang dewasa. Kegiatan dilakukan dalam beberapa tahapan yang meliputi kegiatan koordinasi, sosialisasi, pelatihan dan pendampingan. Hasil evaluasi terhadap pelaksanaan kegiatan menunjukkan adanya peningkatan kapasitas pengawas dan pengurus BUMG Bersama Minapolitan Meurasa Saban terhadap perbaikan tatakelola administrasi dan keuangan BUMG. Hasil kuisioner menunjukkan bahwa 10 orang pengurus $(75 \%)$ pengurus memahami dengan baik seluruh materi pelatihan, sedangkan 5 orang pengurus $(25 \%)$ cukup memahami seluruh materi pelatihan. Tingkat kepuasan peserta pelatihan menunjukkan 12 orang pengurus $(85 \%)$ merasa sangat puas dan 3 orang pengurus $(15 \%)$ merasa puas terhadap pelaksanaan pelatihan. Pengawas dan pengurus BUMG Bersama
\end{abstract}


Baihaqi, dkk. Penguatan Kapasitas BUMG Bersama Minapolitan...

Minapolitan Meurasa Saban telah memahami AD/ART dan TUPOKSI. Sedangkan bendahara dan operator BUMG mampu memahami pencatatan produk berbasis eduteknopreneurship. BUMG Bersama Minapolitan Meurasa Saban telah memiliki rencana pengembangan usaha yang tertuang dalam program kerja tahunan.

Kata Kunci: BUMG Bersama Minapolitan Meurasa Saban, Aceh Timur, Eduteknopreneurship

\section{PENDAHULUAN}

Berdasarkan data Kecamatan Dalam Angka tahun 2019 yang dipublikasikan oleh BPS Kabupaten Aceh Timur, Gampong Bale Buya memiliki luas 3,39 $\mathrm{Km} 2$ yang berbatasan dengan: Sebelah Utara dengan Gampong Seuneubok Aceh, Sebelah Selatan dengan Gampong Seuneubok Peusangan, Sebelah Barat dengan Gampong Dama Tutong dan Sebelah Timur dengan Gampong Matang Gleum. Jumlah penduduk bale buya adalah 558 jiwa dengan perincian 288 laki-laki dan 270 perempuan. Secara geografis gampong ini dikelompokkan dalam daerah pesisir dengan 3 dusun yakni: dusun Keude, Kuburan dan Pesantren. Desa ini juga telah dikelompokkan kedalam kawasan perdesaan prioritas nasional (KPPN) oleh Bappeda Aceh Timur

Sesuai dengan amanat pemerintah yang tertuang dalam Undang-undang Nomor 6 tahun 2014 tentang Desa dan Peraturan Pemerintah Nomor 60 tahun 2014 tentang dana desa yang bersumber dari anggaran pendapatan dan belanja negara. Oleh karena itu untuk mencapai sasaran yang telah digariskan tersebut maka perlu kiranya setiap usaha itu ditata dan dikelola dengan baik agar tidak rugikan siapapun

Pasal 3 Permendes Nomor 4 Tahun 2015 menegaskan bahwa BUM Desa didirikan dengan tujuan antara lain untuk meningkatkan perekonomian desa, mengoptimalkan manfaat aset, meningkatkan usaha masyarakat dalam pengelolaan potensi ekonomi desa, menciptakan peluang dan jaringan pasar, membuka lapangan kerja, meningkatkan pendapatan masyarakat Desa dan Pendapatan Asli Desa, yang kesemuanya diharapkan akan dapat meningkatkan kesejahteraan masyarakat melalui perbaikan pelayanan umum, pertumbuhan dan pemerataan ekonomi desa.

BUMG bersama minapolitan meurasa saban adalah salah satu kelompok usaha produktif yang berkembang di gampong Balee Buya. BUMG ini didirikan pada bulan februari 2017 oleh 5 pemerintahan desa dan masyarakat yakni gampong balee buya, seuneubok pidie, seuneubok peusangan, matang gleum dan kuala leuge Dilihat dari struktur organisasinya BUMG ini telah memiliki penasehat yang merupakan kepala desa dari 5 desa, pengawas, direktur, sekretaris, bendahara dan kepala unit produksi. Saat ini BUMG Bersama Minapolitan Meurasa Saban ini memfokuskan kegiatan pada unit produksi perikanan berupa budidaya ikan air tawar serta pengolahan ikan asin dan unit usaha industri yang terlibat dalam pengolahan kopi, pembuatan aneka produk kerajinan tangan dari daun pandan/seuku. Keberadaan BUMG Bersama Minapolitan Meurasa Saban ini juga menjadi wadah berkumpul beberapa kelompok usaha perempuan yang bergerak pada bidang kerajinan anyaman daun pandan/seuke termasuk diantaranya kelompok usaha perempuan bungong seuke dan bungong chirih.

Walaupun BUMG Bersama Minapolitan Meurasa Saban ini telah beraktifitas sejak tahun 2017, namun masih ditemukan berbagai permasalahan antaranya berkenaan dengan penatausahaan administrasi, pengurus dan anggota BUMG belum memahami tugas pokok dan fungsi (Tupoksi), belum memiliki gambaran kerja (job Des), belum adanya profil BUMG, belum memiliki AD/ART, belum mempunyai 
buku saku anggota, aturan kerjasama dengan pihak ketiga, belum adanya desain sistim informasi, business plan, pencatatan bersifat transaksi manual serta pemasaran produk tanpa memanfaatkan teknologi informasi

Seiring dengan aktifitas usaha yang dilakukan oleh BUMG bersama minapolitan meurasa saban, terdapat keinginan dan motivasi anggota kelompok untuk mengembangkan kapasitas dan usaha melalui optimalisasi penatausahaan BUMG bersama minapolitan meurasa saban berbasis eduteknopreneurship, perbaikan tatakelola administrasi dan keuangan serta membangun jiwa entepreneur bagi pengelola BUMG tersebut. Keinginan yang dimiliki oleh BUMG Bersama Minapolitan Meurasa Saban ini juga diperkuat dalam rencana strategis BUMG Bersama Minapolitan Meurasa Saban tahun 2017-2022 yakni penguatan kapasitas kelembagaan dan pengelola BUMG Bersama Minapolitan Meurasa saban demi mewujudkan BUMG yang mandiri dan berdaya saing di masyarakat. Oleh karena itu, dilakukan kegiatan pelatihan dan pendampingan bagi pengurus BUMG Bersama Minapolitan Meurasa Saban berbasis eduteknopreneurship.

\section{METODE}

Kegiatan pendampingan BUMG Bersama Minapolitan Meurasa Saban melibatkan 15 orang pengurus. Kegiatan pengabdian bagi BUMG Bersama Minapolitan Meurasa Saban berbasis eduteknopreneurship di Kecamatan Peureulak Kabupaten Aceh Timur terdiri atas beberap tahapan antara lain:

\section{Koordinasi Kegiatan}

Kegiatan ini dilakukan dalam rangka menyampaikan rencana pelaksanaan kegiatan untuk kelompok sasaran. Tim pelaksana PKM dalam pertemuan ini menjelaskan secara detail rincian dan jadwal kegiatan yang akan dilaksanakan. Koordinasi ini dilakukan kepada DPMG, DP3AKB pemerintahan kecamatan, kepala desa, pengawas BUMG dan kelompok mitra sasaran.

\section{Sosialisasi Kegiatan}

Sosialisasi merupakan tahap awal dari kegiatan program pengabdian kepada masyarakat yang bertujuan untuk memberikan informasi secara menyeluruh kepada pihak pihak yang terlibat dalam kegiatan ini tentang rencana kegiatan. Kegiatan ini dilakukan dengan metode diskusi secara langsung.

\section{Kegiatan Pelatihan}

Kegiatan pelatihan terdiri dari 8 jenis kegiatan, yaitu :

\section{Pelatihan Penataan Kelembagaan BUMG}

Pelatihan ini bertujuan untuk memberikan pemahaman secara detail tugas dan fungsi dari BUMG sebagai institusi pengerak ekonomi lokal di desa. Melalui pelatihan ini diharapkan peserta memahami fungsi dan peran dari BUMG sebagai kekuatan yang akan bisa mendorong terciptanya peningkatan kesejahteraan dengan cara menciptakan produktivitas ekonomi bagi desa dengan berdasar pada ragam potensi yang dimiliki desa. Dalam pelatihan ini, peserta diberikan materi tentang tujuan pendirian BUMG, sumber daya BUMG, faktor yang memperngaruhi keberhasilan BUMG serta hambatan yang didapatkan dalam pengelolaan BUMG.

\section{Pelatihan Membangun Unit Usaha BUMG}

Pelatihan ini memfokuskan kepada kiat-kiat membangun sesebuah usaha termasuk BUMG Bersama Minapolitan Meurasa Saban. Dalam pelatihan ini peserta dibekali dengan strategi membangun sebuah unit usaha. Materi pelatihan yang diberikan berupa jenis-jenis usaha kecil, mikro dan menengah, keuntungan dalam membangun sebuah unit usaha, pengelolaan administrasi sebuah unit usaha dan penataan sebuah 
unit usaha.

\section{Pelatihan Kewirausahan Berbasis Eduteknopreneurship}

Pelatihan ini memfokuskan kepada bagaimana membangun kewirausahaan berbasis eduteknopreneurship pada BUMG Bersama Minapolitan Meurasa Saban. Teknopreneurship adalah sebuah inkubator bisnis berbasis teknologi yang memiliki wawasan untuk menumbuh kembangkan jiwa kewirausahaan. Dalam pelatihan ini peserta didorong untuk menggunakan informasi teknologi sebagai sebuah sistem dalam mengembangkan usaha. Dalam pelatihan ini peserta diberikan materi tentang bentuk-bentuk pemasaran, perdagangan elektronik (e-commerce), pengertian pasar elektronik, aplikasi pembelian dan penjualan produk secara online dan teknik melakukan pemasaran online dan perdagangan elektronik.

\section{a. Pelatihan Penataan Keuangan}

Pelatihan ini memfokuskan kepada pencatatan keuangan bagi bendahara dan operator BUMG Bersama Minapolitan Meurasa Saban. Dalam pelatihan ini pemateri melihat buku pencatatan keuangan, tatacara penulisan pembukuan keuangan. Dalam pelatihan ini peserta mampu mencatat arus kas dengan baik, perhitungan neraca laba rugi dan pemindahan buku kas. Materi yang didapatkan oleh peserta antaranya tujuan pembukuan, perkembangan omzet penjualan, persediaan barang/jasa, kinerja keuangan dan prinsip dasar akuntansi.

\section{b. Pelatihan Pencatatan Produk Barang}

Pelatihan ini memfokuskan kepada pencatatan seluruh jenis produk yang dijual pada BUMDES Mart Bersama Minapolitan Meurasa Saban. Pencatatan produk ini bertujuan untuk mengetahui aneka jenis produk apa saja yang dipasarkan melalui BUMDES Mart ini serta berupaya menghitung kesediaan stok barang dari masing-masing produk.
c. Pelatihan
Penggunaan
Software Transaksi

Pelatihan ini bertujuan

memperkenalkan penggunaan software transaksi dalam memasarkan aneka jenis produk yang dijual pada BUMDES Mart Bersama Minapolitan Meurasa Saban. Software yang diberikan berisikan seluruh jenis produk yang dipasarkan oleh mitra dimana keunggulan software ini dapat dioperasikan dalam kondisi offline. Software ini berperan mempermudah kerja bendahara dan operator BUMDES Mart Bersama Minapolitan Meurasa Saban. Dalam pelatihan ini staff BUMDES juga diajarkan tata cara menginput aneka jenis produk yang dijual melalui software transaksi itu

\section{d. Pendampingan}

Pendampingan dilakukan setelah kegiatan pelatihan selesai dilaksanakan Kegiatan pendampingan berisi diskusi terkait permasalahan yang dihadapi oleh BUMG Bersama Minapolitan Meurasa Saban dalam mengaplikasikan hasil pelatihan yang telah diberikan sebelumnya.

\section{e. Monitoring dan Evaluasi}

Monitoring dilakukan sewaktu kelompok sasaran mengaplikasikan penggunaan software transaksi dalam memasarkan produk yang dijual pada BUMDES Mart Bersama Minapolitan Meurasa Saban. Evaluasi kegiatan meliputi kinerja pengawas dan pengurus BUMG Bersama Minapolitan Meurasa Saban, tingkat pengetahuan, dan permasalahan yang dihadapi oleh kelompok sasaran. Tingkat pemahaman dan tingkat kepuasan peserta diukur dengan menggunakan angket.

Sedangkan metode yang dipergunakan adalah partisiapsi aktif dimana Poerwadarminto (1991) menyebutkan bahwa partisipasi adalah sejumlah orang yang turut berperan serta dalam suatu kegiatan, keikutsertaan, peran serta. Partisipasi secara formal didefinisikan sebagai turut wewenang baik secara mental dan emosional memberikan sumbangsih kepada proses pembuatan dimana keterlibatan secara pribadi orang yang bersangkutan untuk melaksanakan 
tanggung jawabnya (Hardjasoemantri, 2009). Sedangkan Santoso (1998) menekankan bahwa keberhasilan pembangunan dalam partisipasi masyarakat dapat di ukur dengan melihat bagaimana keterlibatan masyarakat didalam pelaksanaan pembangunan dan seberapa besar kontribusi yang diberikan oleh masyarakat terhadap pembangunan dalam pencapaian tujuan pembangunan.

\section{HASIL DAN PEMBAHASAN}

\section{Kegiatan Sosialisasi Pengabdian Kepada Masyarakat}

Kegiatan sosialisasi dilakukan kepada kabupaten DPMG Aceh Timur, Bappeda kabupaten Aceh Timur, DP3AKB kabupaten Aceh Timur, Pemerintahan Kecamatan Peureulak, Pemerintahan Desa Matang Gleum, Balee Buya, Kuala Leuge, Seuneubok Pidie dan Seuneubok Peusangan serta Pengurus BUMG yang dipusatkan pada aula kantor camat peureulak pada tanggal 11 Juli 2019. Dalam kegiatan ini, tim dosen Universitas Samudra memberikan penjelasan secara mendetail tentang urutan dan jadwal kegiatan pendampingan terhadap BUMG Bersama Minapolitan Meurasa Saban yang direncanakan dilakukan selama 6 bulan.

\section{Kegiatan Pelatihan Penataan Kelembagaan BUMG}

Kegiatan pelatihan ini dilakukan pada tanggal 20 Juli 2019 bertempat di balai pertemuan desa Seuneubok Pidie kecamatan Peureulak kabupaten Aceh Timur. Kegiatan ini diikuti oleh 30 peserta terdiri dari pengawas, pengurus, kelompok usaha perempuan bungong chirih, seuke teulayar, bungong seuke dan perangkat desa matang gleum, seuneubok pidie, seuneubok peusangan, balee buya dan kuala leuge. Dalam kegiatan ini peserta diberikan pemahaman tentang esensi pendirian BUMDES, tujuan pendirian, peraturan yang berkaitan dengan pelaksanaan usaha oleh BUMDES, manfaat BUMDES bagi kesejahteraan kelompok, hambatan pelaksanaan BUMDES serta tugas dan fungsi dari BUMDES sebagai institusi pengerak ekonomi lokal di desa. Kegiatan diawali dengan kontrak belajar yang berisi komitmen dan aturan bagi peserta pelatihan dalam mengikuti rangkaian kegiatan pelatihan. Kontrak belajar penting sebagai upaya untuk menumbuhkan rasa kepemilikan dan korsa peserta terhadap pelatihan sehingga peserta aktif dan bebas mengemukakan pendapatnya untuk menentukan jadwal, peraturan pelatihan, dan kompetensi yang akan dicapai oleh peserta selama progam pelatihan berlangsung (Mujiman 2007; UNDP 2012). Model pembelajaran yang digunakan berupa model pembelajaran orang dewasa. pola pemberdayaan masyarakat usia kerja yang efektif dapat dilakukan dengan menerapkan prinsip-prinsip belajar orang dewasa (Rai 2013).

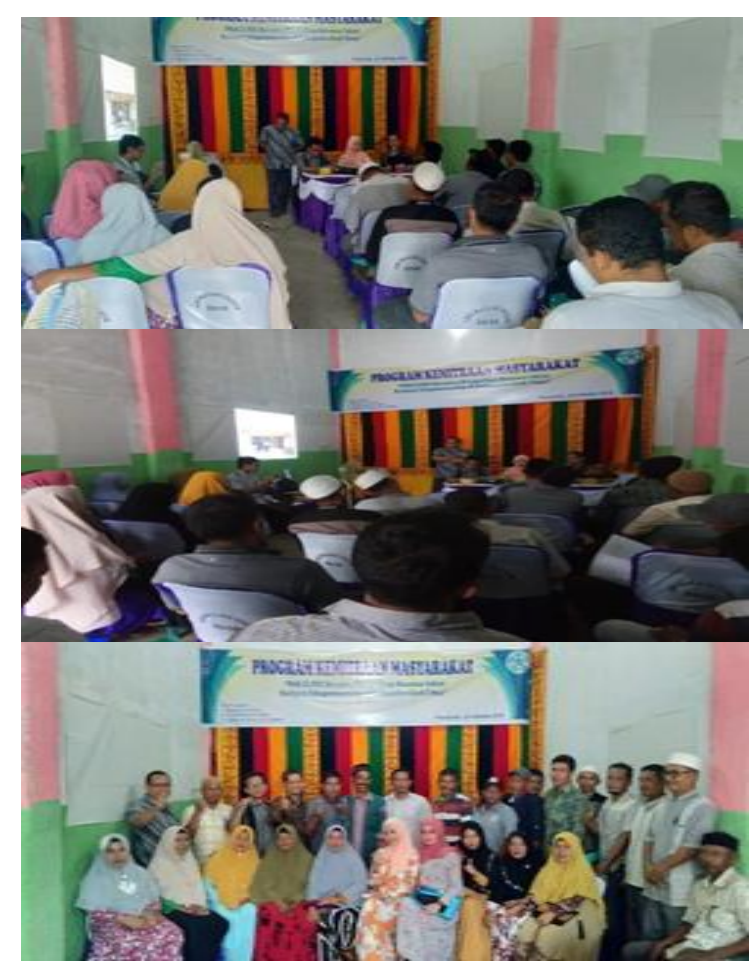

Gambar 1. Pelatihan Penataan Kelembagaan BUMG

Kegiatan ini telah menghasilkan Anggaran Dasar dan Anggaran Rumah Tangga (AD/ART) BUMG Bersama Minapolitan Meurasa Saban serta struktur 
BUMG yang terdiri dari penasehat, pengawas, ketua, wakil ketua, bendahara, sekretaris, koodinator pengembangan SDM serta unit sarana produksi, pemasaran dan kemitraan. Hasil evaluasi di akhir kegiatan pelatihan dengan menggunakan angket menunjukkan bahwa 20 orang peserta $(73,5 \%)$ sangat memahami materi pelatihan, 5 orang $(13,25 \%)$ memahami, dan 5 orang $(13,25 \%)$ cukup memahami materi pelatihan.

\section{Kegiatan Pelatihan Membangun Unit Usaha BUMG}

Pelatihan ini dilaksanakan pada tanggal 23 Juli 2019 yang dikuti oleh 30 orang peserta baik pengurus BUMG maupun kelompok mitra yang memanfaatkan keberadaan BUMG. Materi pelatihan difokuskan kepada kiat-kiat membangun sesebuah usaha termasuk BUMG, jenis-jenis usaha, sistim pemasaran produk, administrasi dalam pengelolaan sesebuah usaha seperti pencatatan transaksi, data keuangan, data pembelian, data penjualan, daftar stok barang, data karyawan dan data pembukuan/perbankan

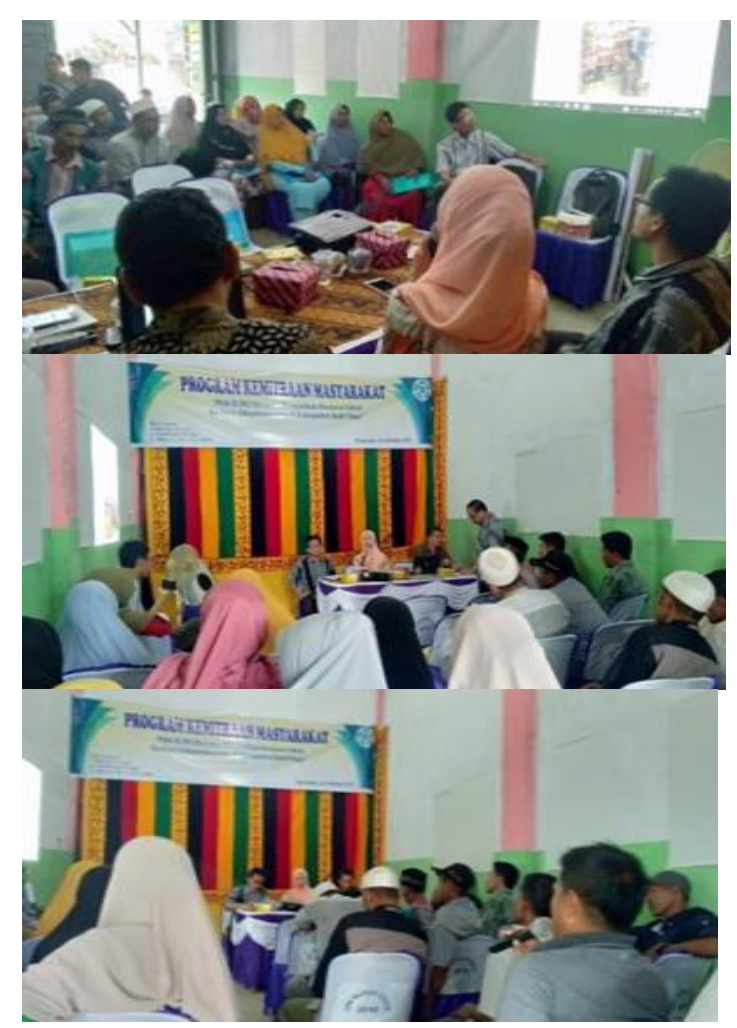

Gambar 2. Pelatihan Membangun Unit Usaha BUMG
Dalam pelatihan ini, narasumber bersama dengan tim pengabdi memberikan masukan untuk perbaikan pengelolaan sebuah unit usaha pada BUMDES Mart Bersama Minapolitan Meurasa Saban antaranya, tata letak produk, pengaturan jenis produk berdasarkan merk produk, harga barang dan pencatatan administrasi dan keuangan. Hasil evaluasi di akhir kegiatan melalui lembar angket yang diisi oleh peserta pelatihan menunjukkan bahwa 24 orang peserta $(78 \%)$ sangat memahami materi pelatihan, 3 orang (11\%) memahami, dan 3 orang (11\%) cukup memahami materi pelatihan.

\section{Kegiatan Pelatihan Kewirausahaan Berbasis Eduteknopreneurship}

Pelatihan ini dilakukan pada tanggal 27 Juli 2019 yang memfokuskan kepada bagaimana membangun kewirausahaan berbasis eduteknopreneurship pada BUMG Bersama Minapolitan Meurasa Saban. Dalam kegiatan ini peserta pelatihan diberikan penjelasan detail tentang definisi eduteknopreneurship

yang merupakan sebuah inkubator bisnis berbasis teknologi yang memiliki wawasan untuk menumbuh kembangkan jiwa kewirausahaan pada masyarakat dan kelompok usaha Inkubator bisnis ini berhubungan langsung dengan aspek pemasaran baik berupa pemasaran online maupun offline. Dalam pemasaran online basis data pelanggan menjadi penting sebagai proses membangun, memelihara dan menggunakan basis data pelanggan termasuk produk, pemasok dan pedagang perantara dengan menggunakan sistim komputer online interaktif. Dalam pelatihan ini juga dijelaskan tentang perdagangan eletkronik (e-commerce), pasar elektronik (market space) dimana penjual menawarkan produkproduk dan jasa secara elektronik dan pembeli mencari informasi, mengidentifikasi apa yang mereka inginkan dan memesan dengan menggunakan kartu kredit atau sarana pembayaran elektronik lain. Saat ini banyak aplikasi yang menawarkan pembelian dan penjualan produk secara 
online seperti: Snapseed, Photogrid, Phorito dan lain-lain.

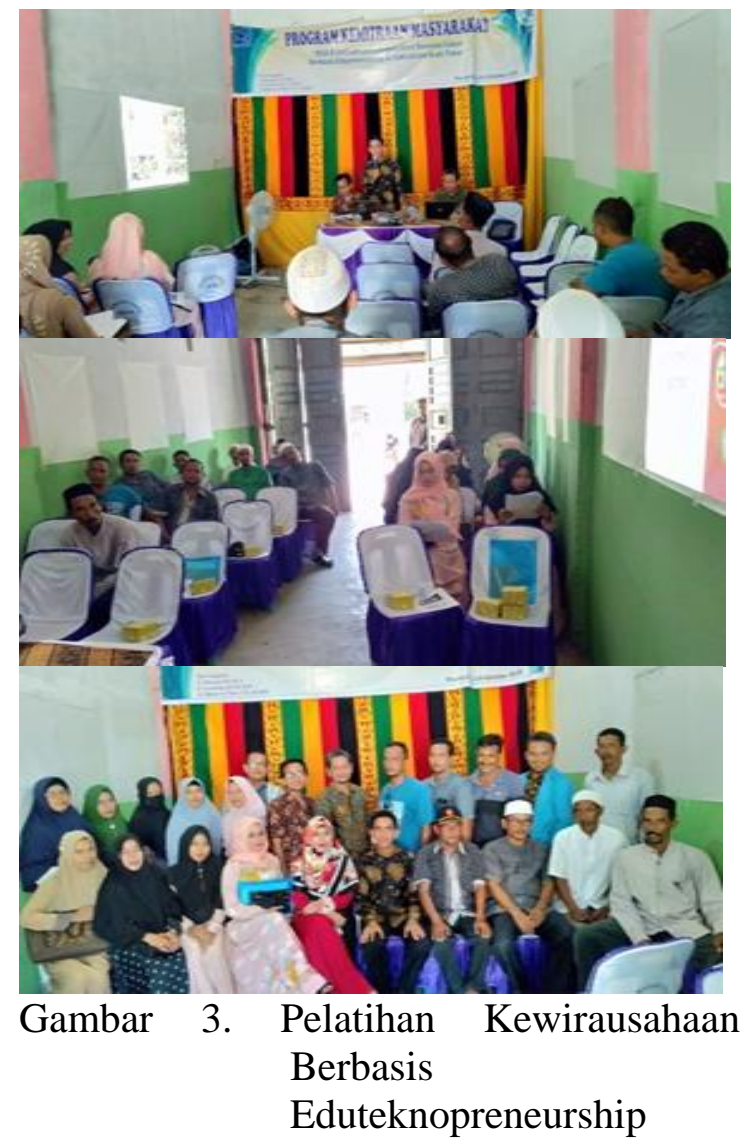

Dalam pelatihan ini, tim pengabdi menyampaikan bahwa aplikasi sistim transaksi berupa software transaksi sedang dirancang oleh tim pengabdi dan sistim kerjanya bersifat offline. Software itu akan diberikan kepada BUMDES Mart Bersama Minapolitan Meurasa Saban bersifat dan dapat digunakan untuk menginput seluruh aneka jenis produk yang dipasarkan oleh BUMDES itu. Diakhir kegiatan tim pengabdi membagikan lembar angket yang diisi oleh peserta pelatihan dimana tercacat bahwa 5 orang peserta (17\%) sangat memahami materi pelatihan, 15 orang $(49,7 \%)$ memahami, dan 10 orang $(33,3 \%)$ cukup memahami materi pelatihan.

\section{Kegiatan Pelatihan Keuangan}

Pelatihan lanjutan ini dilaksanakan pada tanggal 2 Agustus 2019 yang dikhususkan kepada bendahara dan operator BUMDES Mart Bersama
Minapolitan Meurasa Saban. Dalam pelatihan ini peserta diberikan pemahaman tentang pembukuan, kondisi keuangan, perkembangan omzet penjualan, struktur permodalan serta persediaan barang. Dalam kegiatan ini, bendahara dan operator BUMDES Mart Bersama Minapolitan Meurasa Saban diberikan soal berupa pertanyaan yang berhubungan dengan aktifitas pencatatan keuangan yang dilakukan selama ini. Tim pengabdi juga membantu menyediakan buku besar yang berisi tentang pencatatan seluruh produk yang telah terjual mulai periode januari s.d juli 2019 untuk mempermudah bendahara dan operator dalam mengontrol arus kas pada BUMG tersebut.

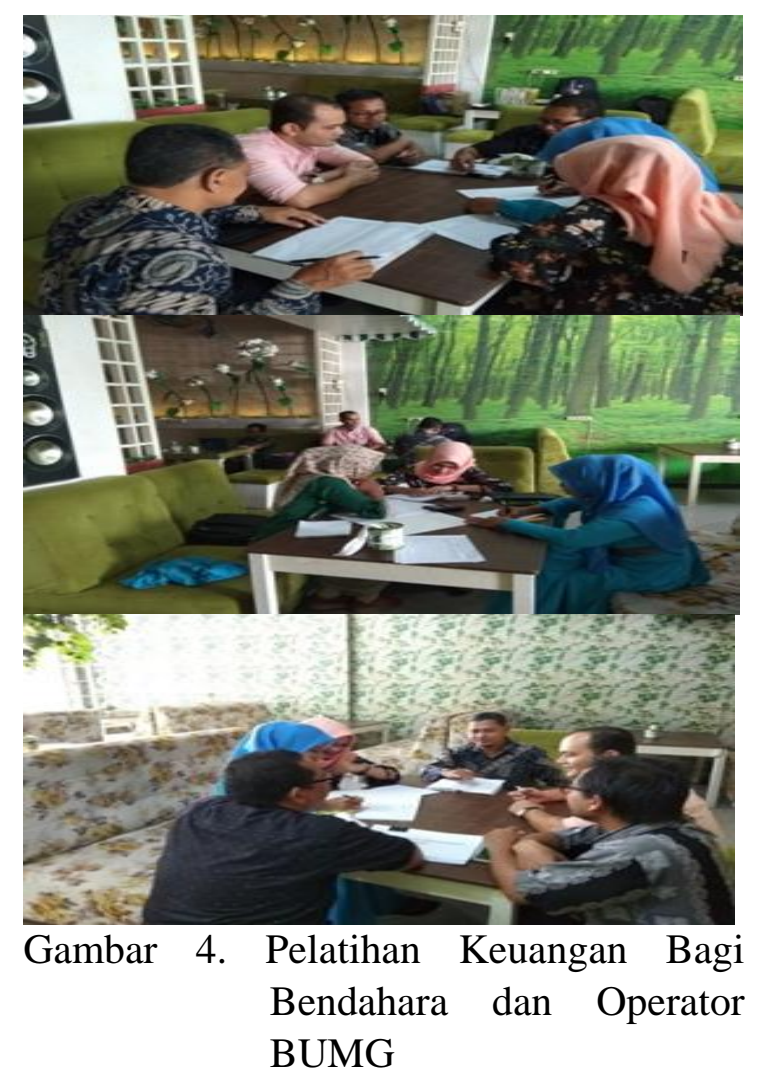

Diakhir pelatihan, tim pengabdi menjelaskan bahwa untuk mempermudah kinerja keuangan BUMDES Mart Bersama Minapolitan Meurasa Saban akan diberikan software transaksi yang berisikan seluruh jenis produk/barang yang dipasarkan pada BUMDES tersebut termasuk perangkat instrument lainnya 
seperti printer, mesin pencetak daftar harga, akses internet dan barcode barang.

\section{Pelatihan Pencatatan Produk Barang}

Pelatihan ini dilaksanakan pada tanggal 7 Agustus 2019 dengan tujuan menginput seluruh pada yang akan di entry pada software. Tim PKM juga menginstal software pada CPU milik BUMDES Mart Bersama Minapolitan Meurasa Saban. Software yang diinstal nantinya akan mempermudah kerja administrasi dan keuangan BUMG Bersama Minapolitan Meurasa Saban.

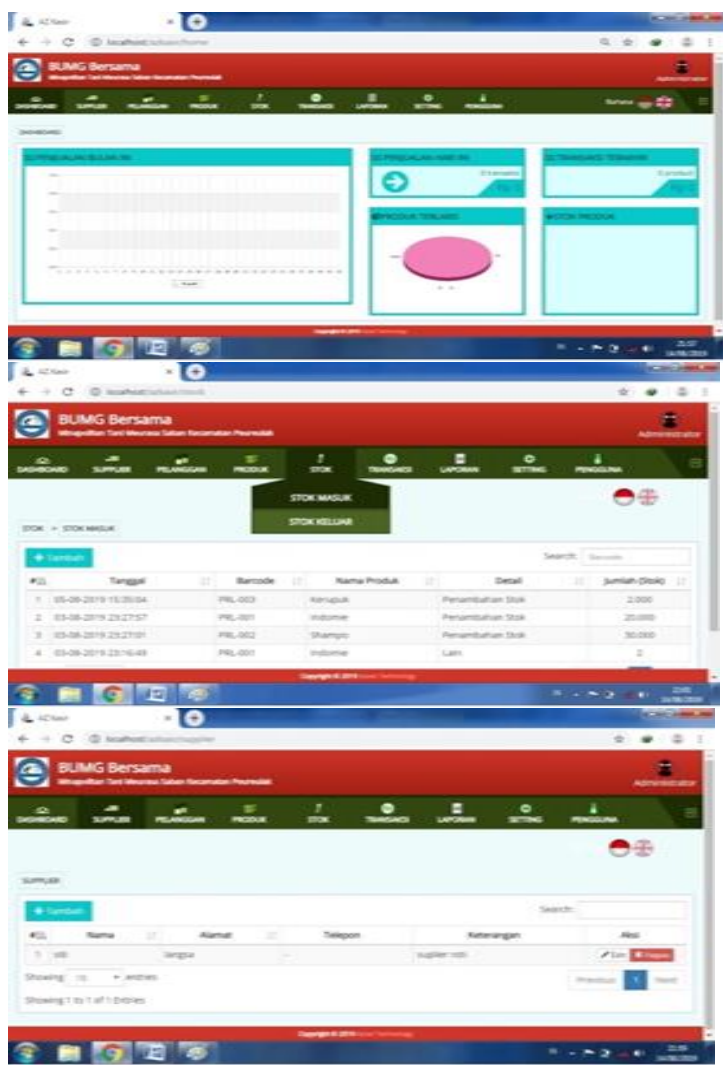

Gambar 6. Tampilan Software Transaksi BUMDES Mart

\section{Monitoring dan Evaluasi}

Hasil monitoring terhadap pelaksanaan kegiatan menunjukkan adanya peningkatan pengetahuan pengawas dan pengurus BUMG terhadap penataan kelembagaan BUMG.. Hasil angket/kuesioner menunjukkan 20 orang peserta $(73,5 \%)$ sangat memahami materi pelatihan, 5 orang $(13,25 \%)$ memahami, dan 5 orang $(13,25 \%)$ cukup memahami materi pelatihan. Sedangkan untuk materi membangun usaha BUMG sebanyak 24 orang peserta $(78 \%)$ sangat memahami materi pelatihan, 3 orang $(11 \%)$ memahami, dan 3 orang (11\%) cukup memahami materi pelatihan. Pada pelatihan kewirausahaan berbasis eduteknoprenership, tercacat bahwa 5 orang peserta $(17 \%)$ sangat memahami materi pelatihan, 15 orang $(49,7 \%)$ memahami, dan 10 orang $(33,3 \%)$ cukup memahami materi pelatihan.

\section{Rencana keberlanjutan program}

BUMG Bersama Minapolitan Meurasa Saban telah menyusun rencana pengembangan usaha yang tertuang dalam program kerja tahunan. Tim pengabdi PKM Universitas Samudra berencana akan melakukan review AD Dan ART BUMG, membuat peta potensi produk unggulan desa, mempromosikan produk yang dipasarkan oleh BUMG melalui jejaring sosial serta membangun kerjasama dengan beberapa BUMDES yang ada di kabupaten Aceh Timur.

\section{SIMPULAN}

Berdasarkan hasil kegiatan pelatihan dan pendampingan bagi BUMG Bersama Minapolitan Meurasa Saban dapat disimpulkan bahwa pengawas dan pengurus BUMG Bersama Minapolitan Meurasa Saban telah memahami tugas, pokok dan fungsi dari BUMG, gambaran kerja (job des) dari masing-masing pengurus, fungsi dan peran dari BUMDES Mart sebagai unit usaha dari BUMG, pengembangan usaha melalui rencana strategis, bendahara dan operator mampu BUMG mampu memahami pencatatan produk berbasis eduteknopreneurship. Hasil angket/kuesioner menunjukkan 20 orang peserta $(73,5 \%)$ sangat memahami materi pelatihan, 5 orang $(13,25 \%)$ memahami, dan 5 orang $(13,25 \%)$ cukup memahami materi pelatihan untuk materi penata usahaan BUMG, sedangkan untuk materi membangun usaha BUMG 
sebanyak 24 orang peserta $(78 \%)$ sangat memahami materi pelatihan, 3 orang (11\%) memahami, dan 3 orang (11\%) cukup memahami materi pelatihan. Sementara untuk pelatihan kewirausahaan berbasis eduteknopreneurship, tercacat bahwa 5 orang peserta $(17 \%)$ sangat memahami materi pelatihan, 15 orang $(49,7 \%)$ memahami, dan 10 orang $(33,3 \%)$ cukup memahami materi pelatihan.

\section{UCAPAN TERIMA KASIH}

Penulis mengucapkan terima kasih kepada Direktorat Riset dan Pengabdian kepada Masyarakat, Kementerian Riset, Teknologi, dan Pendidikan Tinggi RI yang telah mendanai kegiatan pengabdian kepada masyarakat melalui skema Program Kemitraan Masyarakat (PKM) tahun 2019. Penulis juga mengucapkan terima kasih kepada Rektor Universitas Samudra, Pemerintah Kabupaten Aceh Timur, Pemerintah Desa Matang Gleum, Balee Buya, Kuala Leuge, Seuneubok Pidie, Seuneubok Peusangan, pengurus BUMG Bersama Minapolitan Meurasa Saban, dosen dan mahasiswa Universitas Samudra

\section{DAFTAR PUSTAKA}

BPS Kabupaten Aceh Timur. 2019. Kabupaten Aceh Timur Dalam
Angka 2018. Aceh Timur: Badan Pusat Statistik Kabupaten Aceh Timur

Bappeda Kabupaten Aceh Timur. 2017. Penetapan Kawasan Perdesaan Prioritas Nasional

Hardjasoemantri, Koesnadi, 2009, Hukum Tata Lingkungan, Gadjah Mada University Press, Yogyakarta.

Mujiman H. 2007. Manajemen Pelatihan Berbasis Belajar Mandiri. Cetakan II. Yogyakarta (ID): Pustaka Pelajar

Permendes Nomor 4 Tahun 2015 tentang BUM Des

Sastropoetro, Santoso R.A., 1988, "Partisipasi, Komunilasi, Persuasi, dan Disiplin Dalam Pembangunan Nasional", Alumni Bandung.

Undang-Undang No. 6 Tahun 2014 Tentang Desa

United Nations Development Programme (UNDP). 2012. Modul Pengurangan Risiko Bencana Berbasis Komunitas. Jakarta (ID): United Nations Development Programme and Government of Indonesia.

W.J.S, Poerwadarminta .1991, Kamus Umum Bahasa Indonesia, Balai Pustaka, Jakarta. 